\title{
An Alternative Model of Political Education for Political Parties Towards Human Security
}

\author{
V. S. Darvina S, Wahyudi \\ Department of Sociology, Faculty of Social and Political Sciences University of Muhammadiyah Malang \\ Malang, East Java, INDONESIA \\ vina_salviana@yahoo.co.id
}

\begin{abstract}
In Indonesia, the conflicts between political party supporters often happened in the atmosphere ahead of the General Election campaign or Legislative Election where it is usually also accompanied by violence or physical conflicts. This shows the weakness of the internal political education for political parties to constituents. This study considered that the phenomenon of the weak political education on political parties is obviously related to the part of the human security. The findings of the research showed that the national knowledge and political education for political party's cadres and constituents are not optimal. Their knowledge about politics is still limited and more pragmatics. It is caused by the lack of political education from the political party. The solution to solve those problems is to strengthen a political education using alternative model of political education. The model will create qualified constituents and develop the constituents with good national knowledge and political consciousness and reach human security.
\end{abstract}

Keywords—political education, national knowledge, human security.

\section{INTRODUCTION}

The relationship between political parties and their constituents are closely related since it is widely known that in a political life, the people are always supporting political parties. Political parties are expected to be able to channel their aspirations in order to fulfill the people's needs and to make the people's life better. Therefore, the position of political parties as a reference of their constituents is very important, especially in giving information and in building public opinions. Due to the fact, a very firm political system is really needed.

Conflicts and violences or riots often happen when a democracy festivity is held during the campaign. An unhealthy campaign accompanied with various riots is a sign of the damaged public institutional system as shown by broken moral quality and values. Such a society may be said as experiencing the degradation of values and also of morality and this also results in low rational quality. What is developed is emotionality or negative prejudices or inner crises as Novri Susan calls. Indonesian nation is experiencing this crisis, especially, Indonesian people are known as a multi-identity society vulnerable for conflicts or a vulnerable society [1].

The results of a three-year research (2013-2015) showed that either the politicians' or constituents' national konwledge were not too high meanwhile the constituents' political awareness was still limited and their political attitudes tended to be pragmatic in nature. The low national konwledge among the constituents were caused by the lack of socialization process on the nationality in each political parties. Politicians and the people merely possessed high tense of nationality during the political gawe (activities) such as local heads, legislatives and presidential elections. From the first year research findings, problems dealing with political educations in big political parties such as PDIP (Indonesian Democratic Party), Partai Golkar (the Group of Functionaries Party), PKS (Justice Welfare Party) and Partai Demokrat (Democratic Party) are as follows: (1) one problem to attend in the political education is the regeneration of the elites. (2) Not all political parties possess mannuals for the political education. (3) To play politics is not merely for obtaining konwledge on holding states, but for managing a wider life and (4) An ideal model of the political education has not existed yet, but each political party believes that the chosen model is the most ideal one. it:

The expected model of the political education is that

- is intended to build characters

- is the common responsibility

- starts from education in the family

- is should not be doctrinal

- is routinely done

- should be consistent

From the results of the second- and third- year researches, each political party stated that the political education for its cadres is in line with the needs of each party. There were some political parties that did not 
undergo structured and scheduled, but incidental political educations. The education was held before the campaigns of general election or legislatives and also presidential elections. Thus, it is necesary to improve the national konwledge and the political awareness. The main goal of such improvement is the political education since the politial parties have a "duty" to take part in educating their cadress and the people as their partisants. From the description above, it is interesting to investigate how the political educatiom is done in the internal political parties and among the constituents, and to study the model that may be developed in reinforcing the national insight and in improving the people's political awareness in order to avoid conflicts and violence that may make people restless during the local heads, legislative and presidential elections. The most important thing is that this model may be able to make the people secure, remembering that the people have been "tired" with various frictions, violations or stringencies.

\section{THE INTEGRATIVE-PARTICIPATIVE MODEL OF POLITICAL EDUCATION}

The concept "participative-integrative" possesses some important aspects: first, all elements are involved in a program; second, it is important to have clear work divisions that may the program works well; third, the task delegation may develop the feeling of being trusted due to one's capability; fourth, growing motivation among the people may make the program run well; fifth, direct communications among the tutors and the people happens so that they may have the same spirits; sixth, the leadership approach that is transparently made may grow work spirits and personal performance, this may result in the activities run well as planned; seventh there is a synergy among the coordinating institutions, the program implementers and the people [2]. Therefore, when the concept participative-integrative is related to education, it means education that involves many parties with the purpose of giving provisions and awareness of one's capabilities and empowerment that may improve motivation and competence as politicians [3].

The results of a research located in East Java with the subject of politicians from 7 big parties (PDIP, Partai Demokrat, Partai Golkar, Partai Keadilan Sejahtera, Partai Gerindra, Partai Amanat Nasional, and Partai Kebangkitan Bangsa) and their constituents (Salviana and Wahyudi, 2014-2015) showed that the majority understands politics as merely electing legislatives members and the president with the voting model without any understanding of the vision-missions of the candidates or the platform of the party [4]. The candidates' financial capability is a requirement to get a lot of voters. It means that the constituents' political awareness is still at the level of giving votes during the legislative or presidential elections. Political education is important but it is not easy to change and to improve their existing political knowledge. The reformation era has been lasting for 15 years, but most politicians and their constituents have not got a proper understanding of an ideal democracy.

Political education for the 7 parties is varied but there is one similarity: the national knowledge has not been given an enough portion. So, a participative political education is needed.
Participative-integrative political education is a model of political education that involves some participation from all elements either the heads of the political parties, higher education, and the NGOs. Hopefully, an integration between the cadres of political parties and the constitutions may be reached in order to result in highquality and good character politicians and also constituents with adequate national knowledge and political knowledge.

\section{POLITICAL PARTIES AND HUMAN SECURITY}

Political parties have a great role in realizing human security, remembering it is an aspect of the human security political security. Commission on Human Security defines human security as: “...to protect the vital core of all human lives in ways that enhance human freedoms and human fulfillment. Human security means protecting fundamental freedoms - freedoms that are the essence of life. It means protecting people from critical (severe) and pervasive (widespread) threats and situations. It means using processes that build on people's strengths and aspirations. It means creating political, social, environmental, economic, military and cultural systems that together give people the building blocks of survival, livelihood and dignity." [5]

According to Human Security UNDP there are economic security, food security, hunger health security, environmental security, personal security, community security, and political security [6]. The detailed possible types of human security threats, see the following table.

TABLE I. Possible Types of Human SECURITY ThreAtS

\begin{tabular}{|l|l|}
\hline Type of Security & Examples of MainThreats \\
\hline Economic security & Persistent poverty, unemployment \\
\hline Food security Hunger & famine Health security \\
\hline Health security & $\begin{array}{l}\text { Deadly infectious diseases, unsafe food, } \\
\text { malnutrition, lack of access to basic health } \\
\text { care }\end{array}$ \\
\hline Environmental security & $\begin{array}{l}\text { Environmental degradation, resource } \\
\text { depletion, natural disasters, pollution }\end{array}$ \\
\hline Personal security & $\begin{array}{l}\text { Physical violence, crime, terrorism, } \\
\text { domestic violence, child labor }\end{array}$ \\
\hline Community security & $\begin{array}{l}\text { Inter-ethnic, religious and other identity } \\
\text { based tensions }\end{array}$ \\
\hline Political security & Political repression, human rights abuses \\
\hline
\end{tabular}

From the table above it is clear that political repression is a situation that makes the people insecure, especially when human rights abuses happen. Although during the pre- local heads, legislatives and presidential elections, no phenomenon of exceeding political repression exists, insecurity happens. For instance, it is found a thought that it is his political party that is the greatest and the best and the only political party that is good for the political development. It cannot be denied that the event of different choices in the democratic process may cause frictions. An exceeding emotional tie between voters and their candidates will result in some frictions among other voters having too strong social tie with their own candidates. 
A phenomenon of money politic which usually appears in each democracy activity is felt to be able to cause an unpleasant effect during the process of democratization. The politicians of PAN, Gerindra and $P K B$ state that money distribution during general elections may makes the people stupid in the political arena. Cadres of political parties should try to avoid any conflicts and physical clashes especially in the voting places so that voters will not vote other candidates from other political parties. It seems that political security is closely related to community security, meaning that comfort and political security may give impacts on the conditions of comfort and community security.

Conceptually, it has been discussed by Tadjbakhsh and Chenoy that political security components could create positive outcomes in other fields such as reduction of political exclusion (community security), participation of communities (community and personal security), etc. and also create negative potential outcomes such as imposing particular type of governance system (linked to potential community, economic and political insecurities) [7].

\section{CONCLUSION}

From the descriptions above, it can be concluded that the campaign of a general election may cause some insecurity for the people. The candidates of legislative members, of regents/mayors/governors or president or even the supporters of the candidates have some feelings of insecurity from unhealthy competitions (money politic, humiliating the ethnic groups of the candidates or discrediting the religions the candidates believe in, and the like). A participative-integrative political education is felt to be needed by the cadres and constituents, remembering that their national knowledge and political awareness are still low. This model of political education may support the improvement of the attitudes that give some priorities in defending unity and oneness followed by the implementation of the Archipelago concept in political, economic, social, and cultural life and also in defense and security. This in turn may improve the quality and the capability of human resources.

The ideas proposed by Irwan Abdullah on the improvement of the Archipelago concept and the conception of unity in diversity is the conceptions that may be made as the basic reference in nation building and state building. This certainly will build strong characters as the actors supporting the reconcilement and prosperity [8]. So, the involvement of the NGOs and Higher
Education in the political education for cadres of political parties and their constituents is very vital. Political education is not left to grow naturally during this democracy transition. The people should be trapped under the process of making them fool by the existence of money politics or physical conflicts that cause some victims during the democracy festivity.

Therefore, the solution offered to reduce or even to abolish the insecure condition is the synergy among high education, NGOs and political parties to be commonly responsible for the national development in order to realize human resources with high nationality and high sensitivity to create human security.

\section{ACKNOWLEDGMENT}

I gratefully acknowledge that the research was financially supported by the Ministry of Research, Technology and Higher Education of the Republic of Indonesia.

\section{REFERENCES}

[1] Novri Susan. Pengantar Sosiologi Konflik dan Isu-isu Konflik Kontemporer. Jakarta: Kencana Prenada Media Group.2009: p.191.

[2] Vina Salviana and Dyah Erni Widyastuti. Empowering Productive Age Women through Development of Local Potential- based Life Skill Model, Hibah Bersaing Research. Ministry of National Education and Culture of The Republic of Indonesia , Malang.2008: pp 52-56

[3] Vina Salviana and Wahyudi. "An Integrative Participative Model for Strengthening National Knowledge and Political Education to Cadres and Constituents of Political Parties," Journal of Research on Humanities and Social Sciences. New York: Vol.5.No.8: p.16. May 2015.

[4] Vina Salviana and Wahyudi. Penguatan Wawasan Kebangsaan dan Kesadaran Berpolitik Melalui Model Pendidikan Politik Partisipatif Integratif di Propinsi Jawa Timur, Hibah Tim Pascasarjana Research (3 years). Ministry of National Education and Culture of The Republic of Indonesia.

[5] Human Security Unit United Nations. Human Security In Theory And Practice, An Overview of the Human Security Concept and the United Nations Trust Fund for Human. [Karim Hussein, Donata Gnisci, Julia Wanjiru. Security and Human Security: An overview of Concepts and Initiatives, What Implications for New Africa. Sahel and West Africa Club, Paris:2004.p.14].

[6] Commission on Human Security, 2003: p.4.

[7] S. Tadjbakhsh and A. Chenoy, Human Security: Concepts and Implications, London: Routledge, 2007.

[8] Irwan Abdullah. Berpihak pada Manusia: Paradigma Nasional Pembangunan Indonesia Baru, Yogyakarta: TICI Publications. 2010: p.41-58. 